Diterima: 11/03/2020, Direview: 06/05/2020, Diterbitkan: 05/10/2020

\title{
PENGARUH LAMA PENYIMPANAN DAN BAHAN PENGAWET TERHADAP KARAKTERISTIK FISIKOKIMIA NIRA AREN (Arenga pinnata Merr)
}

\section{The Effect of Preservatives and Storage Time on Physicochemical Characteristics of Palm Sap}

\author{
Ferymon Mahulette $^{1 *}$, Zadrak Rupilu ${ }^{2}$, Merry Pattipeilohy ${ }^{1}$ \\ 1). Program Studi Pendidikan Biologi Universitas Pattimura \\ Jl. Ir. M. Putuhena, Ambon, Maluku 97233 \\ 2) Lembaga Pembinaan Khusus Anak Kelas II Ambon \\ Kementerian Hukum dan HAM Provinsi Maluku. \\ Jl. Laksdya Leo Wattimena Passo Ambon, Maluku \\ *Penulis korespondensi, Email: ferymonm@gmail.com
}

\begin{abstract}
ABSTRAK
Nira aren (Arenga pinnata Merr) merupakan bahan dasar berbagai produk yang bernilai ekonomis, seperti gula aren. Pengolahan gula aren memerlukan nira segar sehingga masyarakat sering menggunakan berbagai pengawet untuk mencegah proses fermentasi. Penelitian ini bertujuan untuk mengetahui pengaruh bahan pengawet alami dan lama penyimpanan terhadap karakteristik fisikokimia nira aren. Desain penelitian yang digunakan adalah rancangan acak lengkap pola faktorial. Bahan pengawet yang digunakan adalah kulit buah manggis, kulit buah langsat, dan sabut kelapa, sedangkan parameter fisikokimia yang diukur adalah suhu, $\mathrm{pH}$ dan kadar gula. Penggunaan bahan pengawet dan penyimpanan tidak berpengaruh terhadap suhu, tetapi sangat berpengaruh terhadap $\mathrm{pH}$ dan kadar gula nira aren. Bahan pengawet terbaik adalah kulit buah langsat dengan penyimpanan sehari karena memiliki nilai $\mathrm{pH}$ dan kadar gula yang tinggi masing-masing 3.65 dan 3.0\%. Petani sebaiknya menggunakan kulit langsat untuk mengawetkan nira aren.
\end{abstract}

Kata kunci: Bahan pengawet, Karakteristik fisikokimia, Lama penyimpanan, Nira aren

\section{ABSTRACT}

Palm sap (Arenga pinnata Merr) is a raw material of various products that have economic value, such as palm sugar. Processing palm sugar requires fresh sap, so it needs various preservatives to prevent the fermentation process. This study purpose to determine the influence of preservatives and storage time on the physicochemical characteristics of palm sap. The study design used was completely randomized factorial. Mangosteen rind, lansium rind, and coconut fiber are used as the preservatives, while the physicochemical parameters measured were temperature, $\mathrm{pH}$, and sugar content. The use of preservatives and storage does not affect temperature, but greatly affected $\mathrm{pH}$ and palm sugar content. The best biopreservative was lansium rind with one-day storage because it has high $\mathrm{pH}$ and sugar content of 3.65 and $3.0 \%$, respectively. Farmers should use lansium rind to preserve palm sugar sap.

Keywords: Palm Sugar Sap, Physicochemical Characteristics, Preservative, Storage Tim

\section{PENDAHULUAN}

Aren (Arenga pinnata Merr) adalah tanaman yang tumbuh di daerah tropis. Sebagian besar populasi tanaman ini masih tumbuh liar di hutan dan belum dibudidayakan oleh masyarakat. Berdasarkan taksonomi, aren termasuk keluarga palma yang berkerabat dengan kelapa dan lontar (Fatah dan Sutejo 2015). Tanaman yang juga disebut enau ini merupakan 
tanaman serbaguna karena dapat diolah menjadi berbagai produk. Produk aren yang memiliki nilai ekonomis paling tinggi adalah nira (Ishak et al., 2013). Nira merupakan cairan mengandung gula yang diambil dari bagian tandan bunga tanaman aren (Marianti, 2013).

Di daerah Maluku, nira yang dihasilkan tanaman aren dimanfaatkan untuk mengolah gula atau dibiarkan mengalami fermentasi menjadi arak dan cuka. Nira aren juga dimanfaatkan sebagai starter mikroba (substitusi khamir) untuk membuat kue. Pengolahan nira menjadi berbagai produk dapat meningkatkan pendapatan masyarakat pedesaan (Titabano, Pattinama, dan Thenu, 2017). Nira yang baru disadap belum mengalami fermentasi. Fermentasi berlangsung pada saat nira berada di dalam wadah penampung. Fermentasi menyebabkan nira menjadi asam, keruh dan berbuih. Perubahan tersebut disebabkan oleh aktivitas mikroba, terutama khamir (Karouw dan Lay, 2006).

Pengolahan nira menjadi gula aren harus menggunakan nira segar dan berkualitas tinggi. Nira segar sangat mudah mengalami fermentasi oleh aktivitas mikroba yang ditandai dengan penurunan nilai pH (Haloho dan Susanto, 2015). Pengolahan gula merah minimal memerlukan $10 \mathrm{~L}$ nira. Jika nira yang diperoleh tidak mencukupi, maka pengrajin biasanya menunggu beberapa hari untuk melakukan pengolahan. Agar kualitas nira segar tidak berubah, maka petani biasanya menambahkan beberapa bahan pengawet, baik bahan pengawet kimia, biologis, fisik dan kombinasinya (Karouw dan Lay, 2006). Pengawet biologi yang digunakan antara lain kulit buah manggis, sabuk kelapa dan kulit buah langsat. Penelitian penggunaan sabut kelapa dalam pengawetan nira telah dilakukan oleh Barlina, Karouw dan Pasang (2006), akan tetapi perbandingan penggunaan bahan pengawet alami tersebut dengan bahan pengawet lain belum pernah dilakukan. Penggunaan bahan pengawet pada nira sangat penting karena sebagian besar petani aren adalah pengrajin gula merah yang memerlukan nira segar. Penelitian ini bertujuan untuk mengetahui pengaruh beberapa bahan pengawet alami dan lama penyimpanan terhadap perubahan karakteristik fisikokimia nira aren.

\section{BAHAN DAN METODE}

\section{Bahan}

Sampel nira aren diambil dari hutan Desa Halong, Kecamatan Baguala Kota Ambon sedangkan buah kelapa, manggis dan langsat yang dibeli di Pasar Mardika, Ambon.

\section{Alat}

Penelitian ini menggunakan beberapa peralatan yakni timbangan, baskom, pisau. Alat yang digunakan untuk analisis meliputi termometer, $\mathrm{pH}$ meter, dan refractometer brix sugar.

\section{Desain Penelitian}

Desain penelitian sebagai berikut: (Tabel 1).

Tabel 1. Rancangan Percobaan Nira Aren

\begin{tabular}{cccc}
\hline Lama & \multicolumn{3}{c}{ Jenis Bahan Pengawet } \\
\cline { 2 - 4 } Penyimpanan & Kulit buah manggis(P1) & Kulit buah langsat (P2) & Sabut kelapa (P3) \\
\hline 1 hari $(\mathrm{H} 1)$ & $\mathrm{H} 1 \mathrm{P} 1$ & $\mathrm{H} 1 \mathrm{P} 2$ & $\mathrm{H} 1 \mathrm{P} 3$ \\
2 hari $(\mathrm{H} 2)$ & $\mathrm{H} 2 \mathrm{P} 1$ & $\mathrm{H} 2 \mathrm{P} 2$ & $\mathrm{H} 2 \mathrm{P} 3$ \\
3 hari $(\mathrm{H} 3)$ & $\mathrm{H} 3 \mathrm{P} 1$ & $\mathrm{H} 3 \mathrm{P} 2$ & $\mathrm{H} 3 \mathrm{P} 3$ \\
\hline
\end{tabular}

\section{Tahapan Penelitian}

1. Pengambilan sampel

Nira aren disadap pada sore hari dan ditampung dalam jerigen. Nira yang telah tertampung diturunkan pada pagi hari berikutnya. Sebanyak $5 \mathrm{~L}$ nira kelapa dan dibawa ke laboratorium dalam kondisi mulut jerigen terbuka. Nira kemudian dituang ke dalam 9 
buah gelas kimia masing-masing berisi $500 \mathrm{~mL}$ dan diberi label sesuai tiga jenis bahan pengawet dan tiga waktu penyimpanan.

2. Preparasi bahan pengawet.

Buah manggis dibelah sementara langsat dan kelapa dikupas untuk memperoleh kulit buah dan sabuk kelapa. Semua bahan pengawet dipotong berukuran dadu dan ditimbang. Sebanyak $5 \mathrm{~g}$ pengawet dimasukkan masing-masing ke dalam 9 gelas kimia berisi nira aren, yaitu tiga gelas kimia untuk kulit buah manggis dan enam gelas kimia lainnya untuk kulit buah langsat dan sabut kelapa.

3. Nira aren yang telah ditambahkan pengawet disimpan selama 1, 2 dan 3 hari.

\section{Metode}

Penelitian ini menggunakan Rancangan Acak Lengkap ( $R A L)$ pola faktorial dengan kombinasi perlakuan bahan pengawet dan lama penyimpanan nira aren. Parameter yang diukur adalah suhu, $\mathrm{pH}$ dan kadar gula. Hasil pengukuran dianalisis menggunakan analisis varian kemudian dilanjutkan dengan uji Tukey untuk membandingkan seluruh pasangan rerata perlakuan (Fitri, Fadjryani, dan Rais, 2016).

\section{Prosedur Analisis}

Parameter yang diukur dalam penelitian ini meliputi suhu, $\mathrm{pH}$, dan kadar gula nira aren masing-masing menggunakan termometer (TP 300, China), pH meter (CT-6022 Kedida, China), dan refractometer brix sugar (ATC).

\section{HASIL DAN PEMBAHASAN}

Perubahan suhu selama penyimpanan nira aren dengan menggunakan bahan pengawet kulit manggis, kulit langsat, dan sabut kelapa tidak berbeda jauh dari hari pertama hingga tiga hari penyimpanan yaitu berkisar antara $27.5-27.9^{\circ} \mathrm{C}$. Suhu terendah pada pengawetan menggunakan sabut kelapa pada penyimpanan selama 1 dan 3 hari serta kulit manggis pada penyimpanan 2 hari yaitu $27.6^{\circ} \mathrm{C}$ (Gambar 1). Selama penyimpanan suhu nira aren tidak terjadi perubahan yang mencolok. Menurut Hotijah et al., (2019), proses fermentasi nira berlangsung pada suhu optimum kisaran $27-31^{\circ} \mathrm{C}$. Dengan demikian, selama penyimpanan nira aren telah berlangsung proses fermentasi yang menghasilkan alkohol. Suhu nira aren relatif konstan karena penyimpanan berlangsung dalam kondisi terbuka.

Peningkatan suhu selama penyimpanan nira mengindikasikan tingginya aktivitas mikroba dalam nira. Mikroba yang ditemukan dalam nira adalah khamir dan bakteri. Khamir didominasi oleh genus Saccharomyces dan Candida, sedangkan bakteri didominasi oleh bakteri asam laktat dan bakteri kontaminan, seperti Bacillus dan Escherichia (Chandrasekhar et al., 2012). Sabuk kelapa mengandung sejumlah senyawa polifenol seperti katekin dan epikatekin (Esquenazi et al., 2002). Senyawa-senyawa tersebut berpotensi sebagai anti mikroba yang mampu menghambat pertumbuhan Candida dan beberapa bakteri asam laktat, seperti Lactobacillus dan Streptococcus (Shantaram et al., 2014). Bahan pengawet ini dimanfaatkan sebagai obat tradisional untuk menyembuhkan diare di Brazil (Chakraboty dan Mitra, 2008). 


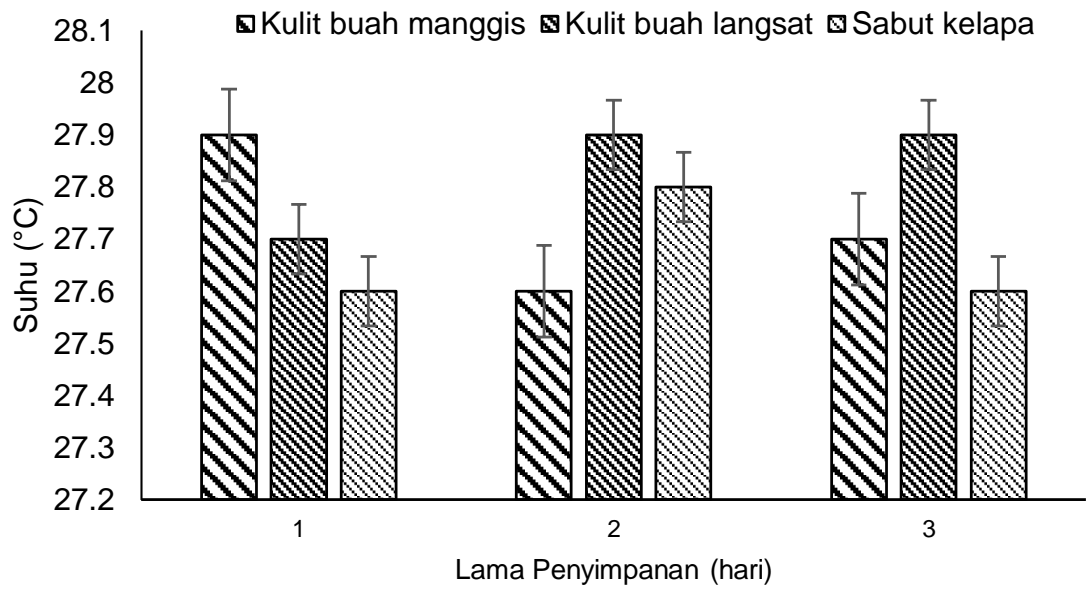

Gambar 1. Perubahan suhu nira aren dengan perlakuan bahan pengawet dan lama penyimpanan

Perubahan $\mathrm{pH}$ selama penyimpanan nira aren dengan menggunakan bahan pengawet kulit manggis, kulit langsat, dan sabut kelapa mengalami penurunan dari hari pertama hingga tiga hari penyimpanan yaitu berkisar antara 4.95-3.64. Nilai $\mathrm{pH}$ tertinggi pada pengawetan menggunakan kulit buah langsat pada penyimpanan selama 1 hari yaitu 9.5 (Gambar 2). Kulit buah langsat mengandung sejumlah senyawa terpenoid seperti asam lansiolik dan lansionik. Senyawa-senyawa tersebut berpotensi sebagai anti mikroba yang mampu menghambat Candida dan Bacillus (Ragasa, Labrador, dan Rideout, 2006). Kedua kelompok mikroba tersebut ditemukan dalam nira Escherichia (Chandrasekhar et al., 2012).

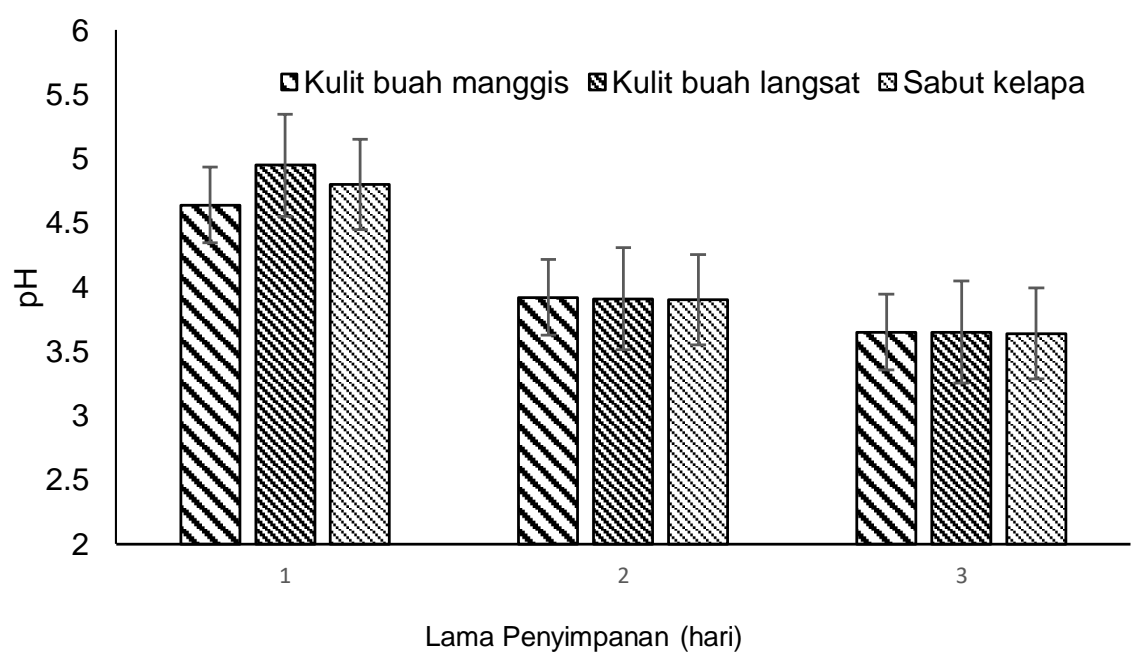

Gambar 2. Perubahan $\mathrm{pH}$ nira aren dengan perlakuan bahan pengawet dan lama penyimpanan

Nira aren segar yang bening dan berasa manis akan menjadi keruh dan masam selama penyimpanan. Rasa masam disebabkan aktivitas mikroba yang memecah gula menjadi asamasam organik. Mikroba yang berperan dalam pembentukan senyawa asam didominasi oleh bakteri seperti Lactobacillus plantarum, Leuconostoc mesenteroides, dan Acetebacter spp (Law et al., 2011). Nilai pH mengalami penurunan sangat mencolok pada hari pertama (4.64-4.95) ke 
hari kedua (3.90-3.92). Menurut Karouw dan Lay (2006), nilai pH nira aren di bawah 4.5 mengindikasikan telah terbentuk asam asetat (cuka) oleh aktivitas bakteri asetat karena penyimpanan dalam kondisi terbuka. Asam asetat terbentuk dari hasil oksidasi alkohol yang dibentuk oleh khamir. Kondisi penyimpanan nira aren tanpa pengadukan memungkinkan khamir dapat membentuk alkohol dalam kondisi anaerob.

Perubahan kadar gula selama penyimpanan nira aren dengan menggunakan bahan pengawet kulit manggis, kulit langsat, dan sabut kelapa mengalami penurunan dari hari pertama hingga tiga hari penyimpanan yaitu berkisar antara 5.3-2.1\%. Kadar gula tertinggi pada pengawetan menggunakan kulit buah langsat pada penyimpanan selama 1 hari yaitu $5.3 \%$ (Gambar 3). Selama penyimpanan kadar gula nira aren semakin menurun karena aktivitas mikroba merombak sukrosa, gula utama dalam nira menjadi asam-asam organik. Kandungan senyawa-senyawa bioaktif dalam bahan pengawet alami mencegah aktivitas mikroba sehingga menghambat proses fermentasi (Sulistyaningrum, Yanto, dan Naufalin, 2015). Aktivitas perombakan gula oleh mikroba dapat dicegah dengan senyawa bioaktif dalam bahan pengawet seperti tanin. Senyawa ini mampu mengikat enzim yang dihasilkan mikroba untuk merombak gula. Hal ini menyebabkan tanin sering digunakan dalam industri pengolahan minuman beralkohol (Barlina, Karouw, dan Pasang, 2006).

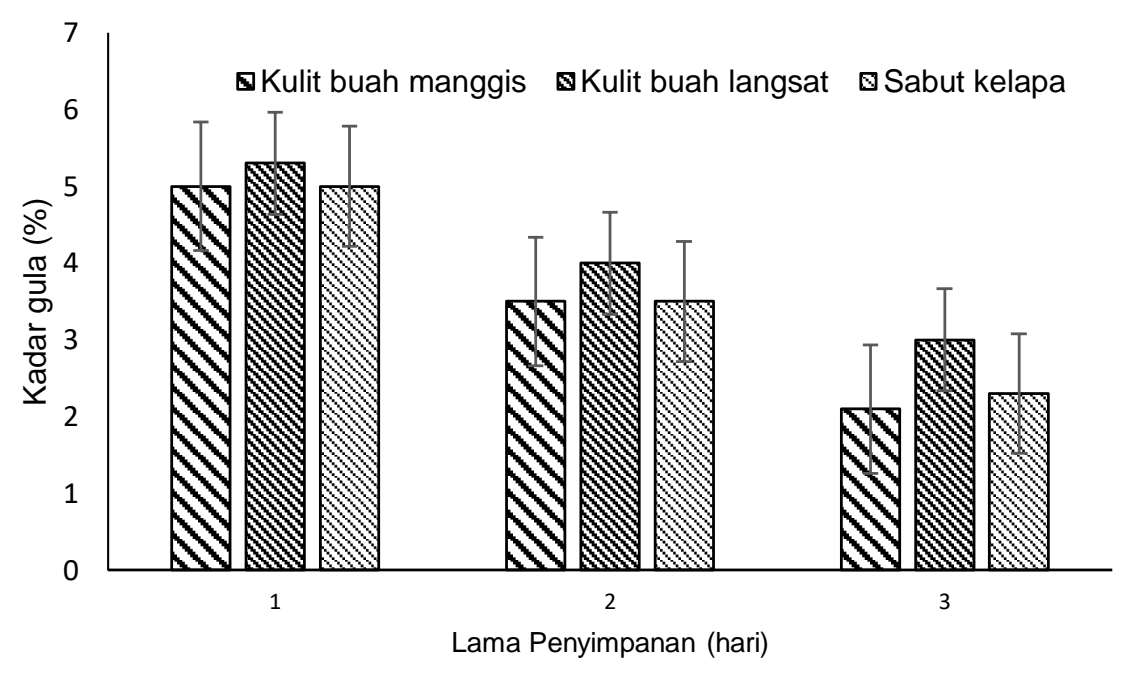

Gambar 3. Perubahan kadar gula nira aren dengan perlakuan bahan pengawet dan lama penyimpanan

Pengawet alami yang digunakan petani untuk mengawetkan nira aren umumnya mengandung tanin. Tanin adalah senyawa polifenol asal tumbuhan yang memiliki rasa pahit dan kelat serta mampu menggumpalkan protein. Kemampuan menggumpalkan protein menyebabkan senyawa tersebut berperan sebagai antimikroba. Kulit buah manggis mengandung tanin dan senyawa polifenol lain seperti xanton, mangostin, garsino, dan flavonoid. Xanton juga berperan sebagai anti mikroba yang dapat menghambat aktivitas bakteri dan fungi (Musita dan Saptaningtyas, 2017). Sabuk kelapa juga mengandung tanin berkisar 8$13 \%$. Hal ini menyebabkan nira yang diawetkan dengan pengawet alami tersebut dapat bertahan selama beberapa jam setelah disadap. Senyawa tanin mampu mengikat enzim yang dihasilkan mikroba sehingga mikroba menjadi tidak aktif (Barlina, Karouw, dan Pasang, 2006). Kandungan tanin yang tinggi menyebabkan kadar gula lebih tinggi pada nira aren yang diawetkan menggunakan sabut kelapa dibandingkan kulit buah manggis.

Penurunan kadar gula sinergis dengan penurunan $\mathrm{pH}$ nira aren. Kadar gula nira aren juga dipengaruhi oleh jumlah mikroba yang merombak senyawa ini menjadi asam. Khamir dan bakteri merupakan mikroba yang sangat berperan dalam menurunkan kadar gula nira aren (Law et al., 2011). Ekstrak kulit buah langsat bersifat anti mikroba yang mampu menekan pertumbuhan beberapa jenis bakteri dan khamir (Korompis, Danes, dan Sumampouw, 2010). 
Hal ini menyebabkan nira yang diawetkan menggunakan kulit buah langsat memiliki kadar gula tertinggi dibandingkan dua bahan pengawet lainnya.

\section{SIMPULAN}

Kulit buah langsat merupakan bahan pengawet terbaik dibandingkan kulit buah manggis dan sabut kelapa karena memiliki nilai pH dan kadar gula yang tinggi masing-masing 3.65 dan $3.0 \%$ pada lama penyimpanan tiga hari. Penurunan nilai $\mathrm{pH}$ dan kadar gula mencolok pada penyimpanan hari kedua. Petani sebaiknya menggunakan kulit buah langsat sebagai pengawet alami dengan lama penyimpanan tidak lebih dari sehari untuk mempertahankan kualitas nira dalam pengolahan gula aren.

\section{DAFTAR PUSTAKA}

Barlina, R., Karouw, S., \& Pasang, P. (2006). Pengaruh Sabut Kelapa terhadap Kualitas Nira Aren dan Palm Wine. Jurnal Penelitian Tanaman Industri, 12(4), 166. https://doi.org/10.21082/jlittri.v12n4.2006.166-171

Chakraboty, M., \& Mitra, A. (2008). The antioxidant and antimicrobial properties of the methanolic extract from Cocos nucifera mesocarp. Food Chemistry, 107(3), 994-999. https://doi.org/10.1016/j.foodchem.2007.08.083

Chandrasekhar, K., Sreevani, S., Seshapani, P., \& Pramodhakumari, J. (2012). A review on palm wine. International Journal of Research in Biological Sciences, 2(1), 33-38.

Esquenazi, D., Wigg, M. D., Miranda, M. M. F. S., Rodrigues, H. M., Tostes, J. B. F., Rozental, S., ... Alviano, C. S. (2002). Antimicrobial and antiviral activities of polyphenolics from Cocos nucifera Linn. (Palmae) husk fiber extract. Research in Microbiology, 153(10), 647652. https://doi.org/10.1016/S0923-2508(02)01377-3

Fatah, A., \& Sutejo, H. (2015). Tinjauan Keragaan Tanaman Aren (Arenga pinnata Merr) di Kabupaten Kutai Barat. Jurnal AGRIFOR, 14(1), 1-14.

Fitri, Y., Fadjryani, F., \& Rais, R. (2016). Perancangan Percobaan Faktorial RAL untuk Analisis Pengaruh Interaksi Umur Beton dan Penambahan Abu Sekam Padi terhadap Kuat Tekan Beton. Jurnal IImiah Matematika Dan Terapan, 11(1). https://doi.org/10.22487/2540766X.2014.v11.i1.7472

Haloho, W. F., \& Susanto, W. H. (2015). Pengaruh Penambahan Larutan Susu Kapur dan STPP (Sodium Tripolyphospat) terhadap Kualitas Gula Kelapa (Cocos nucifera L). Jurnal Pangan Dan Agroindustri, 3(3), 1160-1170.

Hotijah, S., Rofieq, A., Wahyuni, S., Hudha, A. M., \& Fuad Miharja, J. (2019). Pengaruh Waktu Penyadapan Nira dan Lama Penyimpanan terhadap Kualitas Nira Siwalan (Borassus flabellifer L). Prosiding Seminar Nasional, 5, 259-265.

Ishak, M. R., Sapuan, S. M., Leman, Z., Rahman, M. Z. A., Anwar, U. M. K., \& Siregar, J. P. (2013). Sugar Palm (Arenga pinnata): Its Fibres, Polymers and Composites. Carbohydrate Polymers, 91(2), 699-710. https://doi.org/10.1016/j.carbpol.2012.07.073

Karouw, S., \& Lay, A. (2006). Nira Aren dan Teknik Pengendalian Produk Olahan. Bulletin of Palmae, (31), 116-125.

Korompis, G. E. C., Danes, V. R., \& Sumampouw, O. J. (2010). Uji In Vitro Aktivitas Antibakteri dari Lansium domesticum Correa (Langsat). Chem. Prog., 3(1), 13-19.

Law, S. V., Abu Bakar, F., Mat Hashim, D., \& Abdul Hamid, A. (2011). Popular Fermented Foods and Beverages in Southeast Asia. International Food Research Journal, 18, 475484.

Marianti, R. (2013). Potensi Produksi dan Prospek Pengembangan Tanaman Aren (Arenga pinnata Merr) di Kalimatan Timur. Jurnal AGRIFOR, 12(2), 196-205.

Musita, N., \& W.E.Saptaningtyas, W. (2017). Pengaruh Penambahan Pengawet Alami pada Nira terhadap Mutu Gula Aren. Prosiding Seminar Nasional, 1, 220-226.

Ragasa, C. Y., Labrador, P., \& Rideout, J. A. (2006). Antimicrobial Terpenoids from Lansium 
domesticum. The Philippine Agricultural Scientist, 89(1), 101-105.

Shantaram, M., Jose, M., Cyriac, M., Pai, V., \& Varghese, I. (2014). Antimicrobial Properties of Cocos nucifera (coconut) Husk: An Extrapolation to Oral Health. Journal of Natural Science, Biology and Medicine, 5(2), 359. https://doi.org/10.4103/0976-9668.136184

Sulistyaningrum, A., Yanto, T., \& Naufalin, R. (2015). Perubahan Kualitas Nira Kelapa Akibat Penambahan Pengawet Alami. Jurnal Penelitian Pascapanen Pertanian, 12(3), 137-146.

Titabano, H. M., Pattinama, M. J., \& Thenu, S. F. . (2017). Peran Pengelolaan Sumberdaya Alam Tanaman Aren (Sageru) terhadap Pendapatan Masyarakat di Negeri Murnaten Kecamatan Taniwel Kabupaten Seram Bagian Barat. Agrilan: Jurnal Agribisnis Kepulauan, 5(1), 25. https://doi.org/10.30598/agrilan.v5i1.316 